\title{
Audiology
}

\section{Temporal changes in impedance of implanted adults for various cochlear segments}

\author{
Variazioni nel tempo dell'impedenza degli elettrodi nelle diverse partizioni cocleari \\ in adulti con impianto cocleare
}

C.A. LEONE, F. MOSCA, R. GRASSIA

Ear Nose Throat Department, Monaldi Hospital, Naples, Italy

\section{SUMMARY}

Electrode impedance (EI) is the first objective assessment carried out during the surgical procedure and follow-up of cochlear implanted patients. This measure provides information on the integrity of electrodes and on the surrounding environment. It is one of the main factors responsible for energy consumption of the cochlear implant (CI). The aim of our study is to investigate changes over time in EI in adult recipients implanted with the perimodiolar array by comparing differences in various cochlear segments. In addition, we explore the relationship between these objective measures and subjective measures such as T-level and C-level. We studied 28 adult patients. Impedance values (IVs) were calculated in "common-ground" (CG) and in monopolar (M1+2) mode for electrode groups in basal middle and apical segments. We found significant decreases in IVs between activation and 1 month. We obtained higher values for basal impedance, whereas lower IVs were found for apical electrodes at all observation times. Statistical pairing over time between impedance and T/C values showed significant correlation for both global impedance (GI) and T-C levels at CG and M1+2 mode up to 6 months. Segregated statistical analysis also showed a significant and prolonged correlation of basal IVs and fitting parameters. The higher basal impedance over time can be explained by the higher proportion of newly formed tissue in this region. The linear correlation of impedances with the fitting parameters become not significant after 3/6 months for the apical and middle segments and remained significant only for the basal region over time. This behaviour underlines the importance of persistence in intra-cochlear factors in influencing fitting parameters in the basal segment.

KEY WORDS: Cochlear implant $\bullet$ Impedance $\bullet$ Perimodiolar array $\bullet$ Cochleostomy $\bullet$ Cochlear segments

\section{RIASSUNTO}

La prima valutazione oggettiva effettuata durante la procedura chirurgica e nel follow-up dei pazienti sottoposti ad impianto cocleare è la misura dell'impedenza degli elettrodi. Tale misura fornisce informazioni sia sull'integrità degli elettrodi sia sul mezzo circostante gli stessi ed è uno dei principali fattori responsabili dei consumi energetici dell'impianto cocleare. In questo studio abbiamo valutato in pazienti adulti con impianto cocleare e array perimodiolare, le variazioni nel tempo dell'impedenza degli elettrodi, valutando le differenze nelle varie partizioni cocleari (basale, medio e apicale) e correlandone i valori ai principali parametri psicoacustici del mappaggio: livelli di $T$ e C. Abbiamo testato 28 pazienti adulti impiantati presso il nostro Dipartimento tra il 2009 e il 2014, tutti impiantati per via cocleostomica con un array perimodiolare completamente inserito, utilizzando la tecnica chirurgia "soft surgery". Le impedenze medie sono state misurate in modalità "common-ground" $e$ "MP1+2" per i seguenti segmenti di array: basale (dall'elettrodo n.1 al n.7); mediale (dal n.8 al n.14); apicale (dal n.15 al n.22). L'analisi della varianza (ANOVA) è stata effettuata per valutare le tendenze nelle misure ripetute. Il livello di significatività accettato in tale studio è $p<0.05$ corretto con metodo Bonferroni. I risultati hanno mostrato una significativa riduzione globale delle impedenze dall'attivazione fino a 1 mese e un valore più alto nel tempo dell' impedenza nel segmento basale dell'array rispetto al segmento apicale e medio. L'analisi statistica temporale della correlazione tra $i$ valori dell'impedenza globale e i livelli di $T$ e $C$ ha mostrato una correlazione significativa fino a sei mesi sia per le impedenze registrate in common-ground che in modalità MP1+2. L'analisi statistica dei vari segmenti cocleari ha mostrato inoltre una significativa correlazione dell'impedenza nel segmento basale e i parametri del fitting fino ad un anno di follow-up. In conclusione gli alti valori dell' impedenza nel segmento basale nel tempo possono essere spiegati con la formazione di fibrosi endococleare dopo l'inserimento dell'array, fenomeno maggiore nel segmento basale della coclea, limitato invece nelle regioni apicali e medie. La correlazione lineare dei valori dell'impedenza con i livelli di T e C diventa infatti statisticamente non significativa dopo tre/sei mesi nei segmenti apicali e medi e resta significativa fino ad un anno per il tratto basale. Questo comportamento sottolinea l'importanza nel tempo dell'influenza dei fattori intra-cocleari sui parametri del fitting nella porzione cocleare basale.

PAROLE CHIAVE: Impianto cocleare $\bullet$ Impedenza $\bullet$ Elettrodo perimodiolare $\bullet$ Cocleostomia $\bullet$ Segmenti cocleari 


\section{Introduction}

Cochlear implants are helpful tools for hearing function of people with severe to profound hearing loss by means of an electrode system stimulating remaining intra-cochlear neuronal cells. The considerable interest from the scientific community and manufacturers in the fields of bioelectrical and physiological engineering of the ear has led to many studies on implants that have clarified hitherto unknown aspects of the functioning of the cochlea ${ }^{12}$. Certainly, the structure of a cochlea stimulated by an electrode in situ that delivers the current is totally different from a normal cochlea for mechanical, electrical and bioelectric reasons.

It seems evident that the first critical point of the sequential process from sound stimulus to auditory comprehension can be identified in the cochlea-electrode interface and in the number of residual cells activated by the current output.

The latter variable is not quantifiable except in post-mortem studies, and even in these cases there is no consistent evidence for a correlation between residual ganglion cells and auditory performance ${ }^{3-5}$. Evidence from animal research shows that reductions and/or changes in the composition of perilymphatic fluid or adjacent electrode structures, as well as tissue modifications, lead to elevation of the contact impedance: this variation interferes with the efficiency and quality of neural stimulation ${ }^{6}$. Other works report that the histological structure of an implanted patient's cochlea changes in a typical pattern as a result of injury to the lateral wall in the region $8-15 \mathrm{~mm}$ from the round window, and it is often accompanied by new fibrous tissue and bone growth that can change the electrical conduction ${ }^{7}$. Under experimental conditions, deaf implanted cochleae compared to non-implanted deaf cochleae show great variations in the basal turn in terms of the number of hair cells, peripheral processes and damage to the stria and spiral ligament ${ }^{8}$. Measurement of cochlear electrode impedance provides information on the integrity of the array with the electrical surrounding medium. Impedance is opposition to current flow and is made up of capacitance and resistance; the first is related to the characteristics of electrode/fluids interfaces, and the second occurs when electrons pass through a medium and lose energy, which depends on the properties of the materials. Capacitance and resistance cannot simply be summed to achieve a total resistance. Clark ${ }^{9}$ found a positive correlation between the grading of tissue around the electrode and impedance. In addition, electric flow affects electrode impedance: it is a common finding that without stimulation impedance increases.

Electric impedance seems to be primarily related to resistive structure of fluids and tissues around electrodes ${ }^{10}$. Other electrophysiological tests for cochlear implant evaluation are Electrical Advisory Brainstem Response
(EABR) and Neural Response Telemetry and Stapedial Reflex. Our choice for recording impedance changes over time is motivated by several important factors: impedance is an objective intra-cochlear measure that provides information on the integrity of electrodes, on the surrounding environment and is one of the main factors responsible for the energy consumption of the cochlear implant. It is not influenced by number of surviving nerve VIII fibres.

The current steering from an electrode to a non-inert biological system can modify the system itself. Thus, the current intensity regulation necessary to deliver minimum or maximum sensations can vary over time because the reactive conditions of the biological system vary themselves. In fact, from a practical standpoint during the starting phases of the fitting, the same current level can provoke inferior acoustic sensations over time compared to successive follow-ups which are corrected with an increase of the energy pulses. Thus, even impedance variations can influence T- and C-levels if coupled to retro-cochlear factors. We wished to investigate this in a cohort of patients where a variability of the couples impedance/current exists, and if there exists a relationship between impedance values and subjective sensations.

In the literature there are several studies about changes over time in electrical stimulation levels and electrode impedance values in children ${ }^{11-13}$ and in patients implanted with a straight array ${ }^{14}$. Most of these studies evaluated a short follow-up period ${ }^{15}{ }^{16}$, even though there are a some studies where impedances in the various cochlear segments have been analysed. In our study, in addition to previous studies, we evaluated the impedance variations over time only in adult patients implanted with a perimodiolar cochlear implant system with a longer follow-up (compared to the 12 weeks of Busby ${ }^{15}$ or 9 months by Wermeskerken ${ }^{16}$ ). Furthermore, we assessed differences in the various cochlear segments by evaluating the correlation to the main fitting psychoacoustic parameters. In summary, our study purposes are:

1) Statistical evolution over time of impedance.

2) Statistical pairing over time between impedance and $\mathrm{T} / \mathrm{C}$ values.

3) Segregated statistical analysis for apical, middle and basal electrodes over time.

\section{Materials and methods}

All procedures contributing to this work comply with the ethical standards of the relevant national and institutional guidelines on human experimentation (D.L. 24 giugno 2003, n. 211 Attuazione della direttiva 2001/20/ CE relativa all'applicazione della buona pratica clinica nell'esecuzione delle sperimentazioni cliniche di medicinali per uso clinico. G.U. n. 184 del 9-8-2003- Suppl. n. 130) and with the Helsinki Declaration of 1975, as revised in 2008. 
Twenty-eight adult patients implanted at our Department were studied with an age between 18 and 58 years, 16 males and 12 females, 23 perilingually and 5 postlingually deafened, implanted in the period between 2009 and 2014. Aetiology of deafness included: meningitis $(\mathrm{n}=1)$, neonatal sepsis $(\mathrm{n}=1)$, neonatal hypoxia $(\mathrm{n}=2)$, neonatal jaundice $(\mathrm{n}=2)$, rubella during pregnancy $(n=1)$, postnatal measles $(n=1)$, genetic $(n=4)$, multiple sclerosis $(n=1)$, stroke $(n=1)$, unknown $(n=14)$. Aetiology of deafness remained unknown in 50\% cases, while in $28.57 \%$ was due to environmental factors, $14.28 \%$ to genetic causes and $7.14 \%$ to other clinical features.

Our study protocol included repeated assessments, post-implant, at the following intervals: at time of activation, approximately 30 days post-surgery (mean 28.5 days) (t0); and postactivation, 1 month (t1); 3 months ( $\mathrm{t} 3$ ); 6 months (t6) and one year (t12).

All subjects were good implant users (daily on-time $>$ 10 hours). No differences were noted between perilingually or postlingually CI users regarding daily time of use.

In every case, the same type of perimodiolar array was implanted, the Cochlear ${ }^{\text {TM }}$ Nucleus ${ }^{\circledR}$ CI24RE-CA (22 intracochlear electrodes along the array and 2 extra-cochlear electrodes). We used the same surgical technique (cochleostomy), performing manual and progressive introduction of the array, removing the stylet and, at the end, always using recommended precautions of soft surgery for this type of device and always using topical steroids (betametasone) over the cochleostomy site and to soak the electrode before cochlear insertion ${ }^{17-20}$.

Patients with an incomplete electrode array insertion, cochlear malformations or impedance values for one or more electrodes of greater than $20 \mathrm{k} \Omega$ at any time during the follow-up period were excluded as well as cases with bilateral implants.

All processors were fitted with consistent parameters using the ACE strategy, with the same default fitting parameters for stimulation rate (stimulation frequency) $=900 \mathrm{pps}$ (pulses per second) and pulse widths (the amount of time the stimulator delivers current, expressed in microseconds $(\mu \mathrm{s})$ per phase of the biphasic current pulse $)=25 \mu \mathrm{sec}$.

Electrode impedances were measured using software supplied by the manufacturer. The measurement stimuli were biphasic current pulses presented using a current level of 100 clinical units, which are approximately $76 \mu \mathrm{A}$, and with pulse duration of $25 \mu \mathrm{s} / \mathrm{phase}$.

At the beginning of each session, the electrical impedances in $\mathrm{k} \Omega$ and the subjective values of T-level and C-level for each electrode were measured. Average values were calculated for the impedances measured in "commonground" (CG) mode and in monopolar (M1+2) mode. In $\mathrm{CG}$, the impedance is measured between an intra-cochlear electrode and all other intra-cochlear electrodes coupled in parallel: such a measure is only related to cochlear variables. In M1+2 mode, the impedance is measured between the intra-cochlear electrode and the sum of two reference electrodes placed one under temporal muscle and the other over the body of implant at the level of the temporal bone. This monopolar stimulation is used as default in clinical conditions by the ACE strategy.

Mean values were evaluated for electrode array segments as follows: basal (from No. 1 to 7); middle (from No. 8 to 14); and apical (from No. 15 to 22).

Mean impedances were evaluated for the different time intervals of observation and by statistical comparison of the temporal evolution of the values of T-level and C-level over time. The statistical test employed was the Student's t-test. T- and C-level were evaluated as standard procedure with a subjective approach ${ }^{21}$ to be independent from any objective measure which could be influenced by impedances themselves, software a priori, or other.

Impedances and $\mathrm{T}$ - and $\mathrm{C}$-level variations were compared by using the linear regression test. The probability level used was $\mathrm{p}<0.05$ and Bonferroni corrected. Regressions were calculated between mean T- and C-level and impedances for each observation period, as well as for each cochlear segment.

The array used in this study has different electrode surfaces according to their position along the cochlea. The largest surface areas are located in the basal region, while the smallest are located in the apical region: basal electrode (1-10) area is $0.230 \mathrm{~mm}^{2}$, middle electrode (11-16) area is $0.223 \mathrm{~mm}^{2}$, apical one $(17-22)$ is $0.212 \mathrm{~mm}^{2}$ (data reported with permission of manufacturer).

To avoid that a difference in behaviour of the basal impedances compared to middle and apical ones could be due to the electrode surface, the impedance values were corrected by the area multiplicative factor.

\section{Results}

Raw data of $\mathrm{T} / \mathrm{C}$ and impedance values are reported in Table I.

\section{Statistical evolution over time of global impedance}

The results showed an overall trend for the impedances with a significant variation between $\mathrm{t} 0$ and $\mathrm{t} 1$, similar to those reported by Busby ${ }^{15}$. An analysis of variance (ANOVA) was performed to evaluate trends in the repeated measures, and unexpected significant late reduction could be identified only in M1+2 (Fig. 1a).

Statistical pairing over time between global impedance and $T / C$ values

Statistical pairing over time between impedance and $\mathrm{T} / \mathrm{C}$ values showed significant correlation between global impedance (GI) and T-levels up to t6 and between GI and C-levels up to t6 for impedances calculated in CG mode. The same times of significant correlations were noted if 
Table I. Impedance values (corrected per electrode surface), T-level. C-levels for basal-middle-apical segregations; (mean \pm standard deviation).

$\begin{array}{lccccccc}\text { Mean } \pm \text { std. dev. } & & \text { t0 } & \text { t1 } & \text { t3 } & \text { t6 } & \text { t12 } \\ & & \text { Basal } & 2.93 \pm 0.51 & 1.76 \pm 0.41 & 1.79 \pm 0.45 & 1.83 \pm 0.44 & 1.88 \pm 0.43 \\ & \text { GG } & \text { Middle } & 2.77 \pm 0.61 & 1.51 \pm 0.40 & 1.47 \pm 0.38 & 1.47 \pm 0.44 & 1.44 \pm 0.35 \\ \text { Impedances } & \text { Apical } & 2.48 \pm 0.65 & 1.40 \pm 0.38 & 1.33 \pm 0.37 & 1.34 \pm 0.42 & 1.22 \pm 0.34 \\ & \text { Masal } & 3.02 \pm 0.45 & 1.97 \pm 0.40 & 2.00 \pm 0.43 & 2.10 \pm 0.47 & 2.14 \pm 0.44 \\ & \text { MP1+2 } & \text { Middle } & 2.93 \pm 0.59 & 1.79 \pm 0.38 & 1.76 \pm 0.36 & 1.82 \pm 0.48 & 1.76 \pm 0.36 \\ & & \text { Apical } & 2.64 \pm 0.60 & 1.66 \pm 0.38 & 1.60 \pm 0.37 & 1.65 \pm 0.46 & 1.50 \pm 0.37 \\ \text { T-level } & \text { Basal } & 111.78 \pm 25.25 & 135.88 \pm 21.14 & 145.71 \pm 15.82 & 146.32 \pm 14.09 & 147.22 \pm 14.94 \\ \text { Middle } & 107.64 \pm 24.55 & 131.11 \pm 21.87 & 143.08 \pm 16.92 & 144.36 \pm 14.79 & 146.55 \pm 13.52 & \\ \text { Apical } & 106.92 \pm 25.03 & 130.95 \pm 22.85 & 142.59 \pm 17.23 & 143.00 \pm 16.30 & 147.02 \pm 14.12 & \\ & \text { B-level } & 145.69 \pm 16.81 & 183.73 \pm 21.37 & 195.26 \pm 16.70 & 197.31 \pm 12.47 & 199.68 \pm 10.97 & \\ \text { Middle } & 142.51 \pm 17.57 & 181.16 \pm 23.16 & 192.85 \pm 17.64 & 194.76 \pm 16.23 & 199.31 \pm 13.94 & \end{array}$

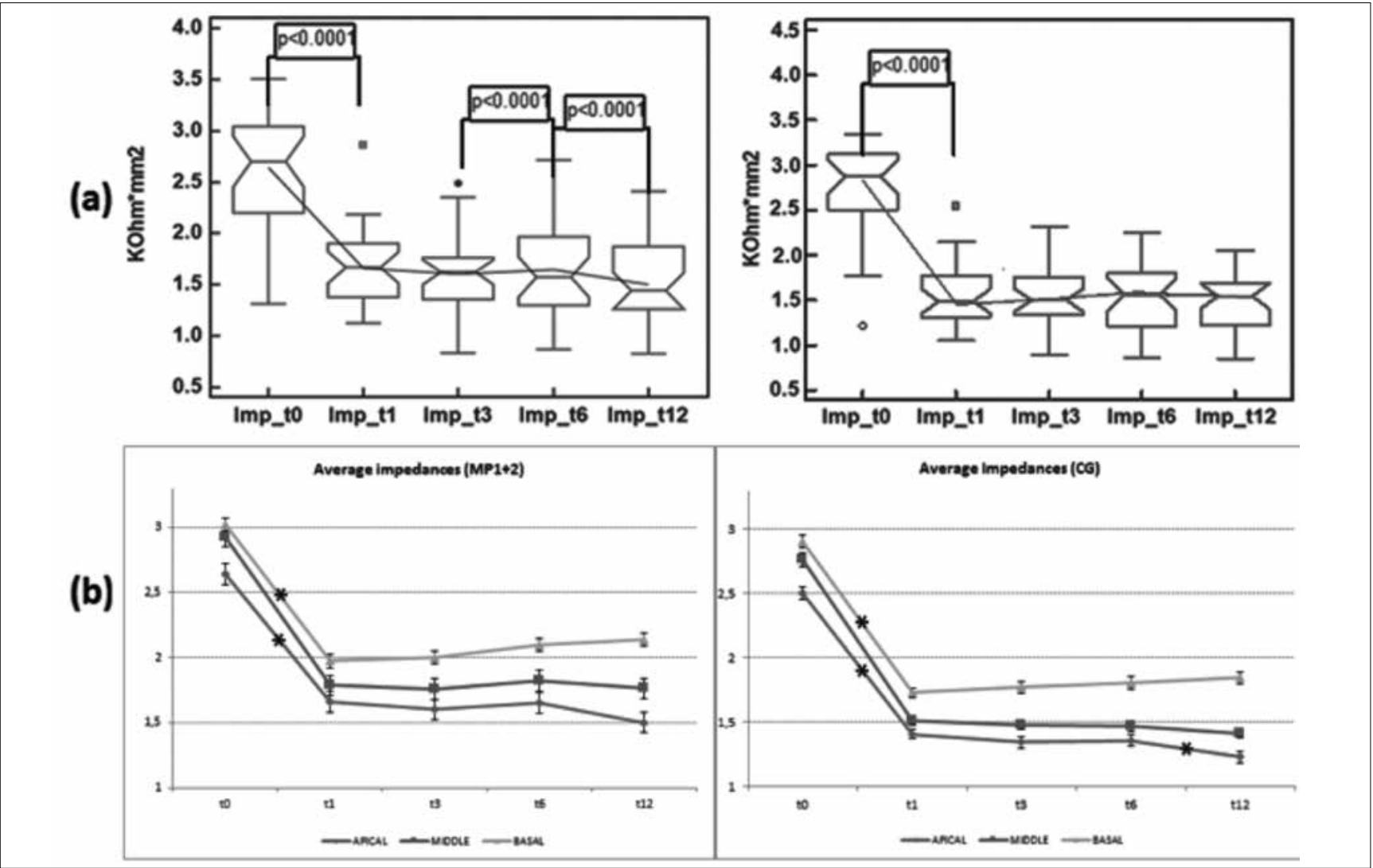

Fig. 1a. Top-left: overall change of impedance corrected by surface in MP1+2 mode; Top-right: overall change of impedance corrected by surface in CG mode; $n=28$, significant time differences are shown. The middle line represents the median. In the notched box-and-whisker plot, confidence intervals for the medians are provided by means of notches surrounding the medians. The vertical line extends from the minimum to the maximum value, excluding outside (smaller/larger than the lower/higher quartile \pm 1.5 times the interquartile range) and far outside values (smaller/larger than the lower/higher quartile \pm 3 times the interquartile range). b. Time sequence of the impedances corrected by surface in MP1+2 mode (lower-left) and in CG mode (lower -right) differentiated by apical, middle and basal electrodes. Asterisk $\left(^{*}\right)=$ significant variations.

impedances were calculated in M1+2 mode (Table II) and Figures $2 a$ and $2 b$.

\section{Segregated statistical analysis for apical, middle} and basal electrodes over time

We conducted the same statistical analysis for each coch- lear region by differentiating electrodes into their basal, middle and apical segments.

The results presented for the corresponding array segments (Table I and Fig. 3) showed that the absolute values of the basal impedances are much higher at all evaluation times with significant differences with respect to apical 
Table II. significant correlations ( $\mathrm{p}<0.05$ Bonferroni corrected) for T- and $\mathrm{C}$-levels in CG mode and in $\mathrm{M} 1+2$ mode.

\begin{tabular}{lccc}
$\begin{array}{l}\text { Sensation } \\
\text { levels }\end{array}$ & $\begin{array}{c}\text { Cochlear } \\
\text { segment }\end{array}$ & $\begin{array}{c}\text { Significant correlations with } \\
\text { impedance } \\
\text { at different time points }\end{array}$ \\
& & Common Ground & MP1 +2 \\
$C$ & Global & $\mathrm{t} 1-\mathrm{t} 3-\mathrm{t} 6$ & $\mathrm{t} 1-\mathrm{t} 3-\mathrm{t} 6$ \\
$\mathrm{~T}$ & Global & $\mathrm{t} 1-\mathrm{t} 3-\mathrm{t} 6$ & $\mathrm{t} 1-\mathrm{t} \mathrm{t}-\mathrm{t} 6$ \\
$\mathrm{C}$ & Apical & $\mathrm{t} 1-\mathrm{t} 3$ & $\mathrm{t} 1-\mathrm{t} 3-\mathrm{t} 6$ \\
& Middle & $\mathrm{t} 1-\mathrm{t} 3$ & $\mathrm{t} 1-\mathrm{t} 3-\mathrm{t} 6$ \\
& Basal & $\mathrm{t} 0-\mathrm{t} 1-\mathrm{t} \mathrm{-}-\mathrm{t} 12$ & $\mathrm{t} 1-\mathrm{t} 3-\mathrm{t} 6$ \\
$\mathrm{~T}$ & Apical & $\mathrm{t} 1-\mathrm{t} 3$ & $\mathrm{t} 1-\mathrm{t} 3-\mathrm{t} 6$ \\
& Middle & $\mathrm{t} 1-\mathrm{t} 3$ & $\mathrm{t} 1-\mathrm{t} 3-\mathrm{t} 6$ \\
& Basal & $\mathrm{t} 1-\mathrm{t} 3-\mathrm{t} 6-\mathrm{t} 12$ & $\mathrm{t} 1-\mathrm{t} 3-\mathrm{t} 6$ \\
\hline
\end{tabular}

and middle segments. A clear correlation between T-level, $\mathrm{C}$ - level and impedances in $\mathrm{M} 1+2$ were shown from $\mathrm{t} 1$ up to t6 for the apical, middle and basal segments. In CG mode, $\mathrm{T}$ and $\mathrm{C}$ correlates up to $\mathrm{t} 3$ for apical and middle segments, but a surprising positive correlation was observed up to 12 between basal electrodes versus $\mathrm{T}$ and $\mathrm{C}$. A clear correlation between T-level, C-level and impedances in $\mathrm{M} 1+2$ were shown from t1 up to t6 (Table II).

A remarkable difference between $\mathrm{CG}$ and $\mathrm{M} 1+2$ was the prolonged significance up to $\mathrm{t} 12$ for the basal electrodes (Table II).

The $p$ values of $t$ tests for impedances, evaluated at different time points, were significant between basal and apical electrode segments and between basal and middle segments at each interval over the observation period (Table III). Less significant differences were observed for comparison of impedances in apical versus middle segments when compared in $\mathrm{CG}$ mode (excluded t0 and $\mathrm{t} 12$ at MP1+2) (Fig. 3).

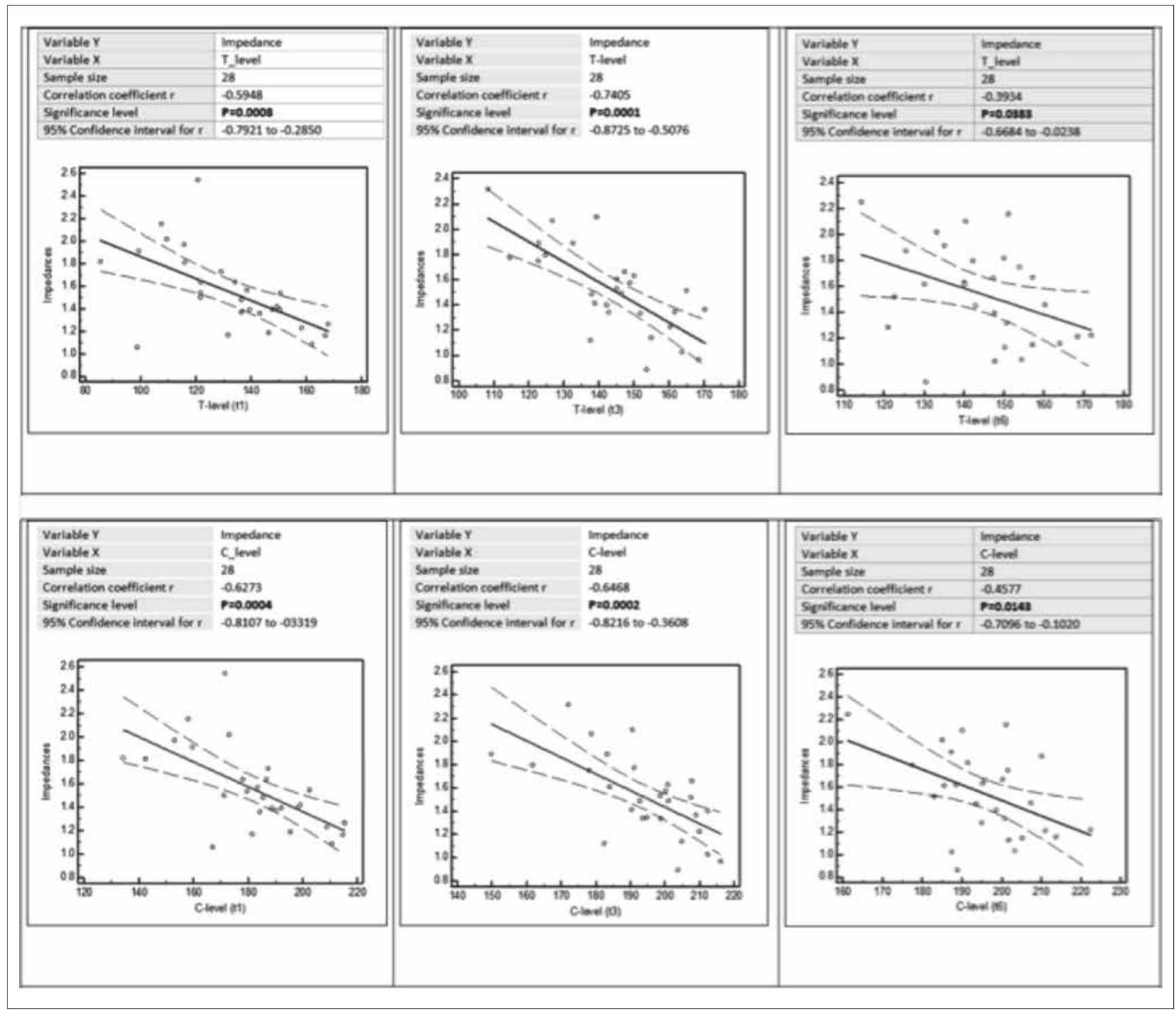

Fig. 2a. Linear correlations between T-level and global impedance; significant values at t1, t3 and t6. b. Linear correlations between C-level and global impedance; significant values at $\mathrm{t} 1, \mathrm{t} 3$ and $\mathrm{t} 6$. 


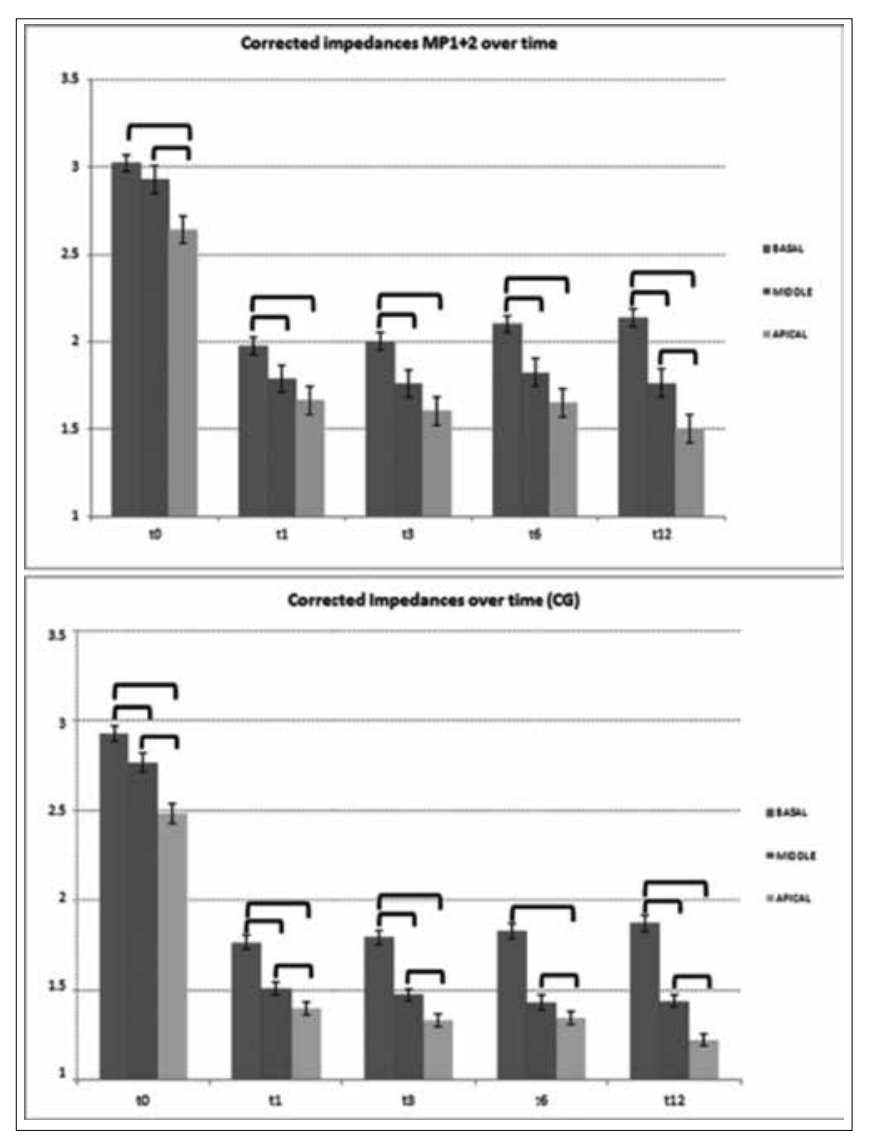

Fig. 3. Histograms depicting average values of the impedances in $M 1+2$ and $C G$ mode in the various cochlear segments and at various evaluation times; in brackets, groups with significant variations.

\section{Discussion}

\section{Statistical evolution of global impedance over time}

The evaluation of our impedance data overall agrees with literature reports 15162223 ; where the maximum values are recorded at 0 followed by a decrease immediately after activation of the sound processor.

In experimental animal studies, the impedance changes reduce around the 45th day ${ }^{24}$. In humans, a reduction in the average impedances was observed during the first weeks and although impedances tended to increase with the use of the cochlear implant, no statistically significant differences were found between the following months ${ }^{25}$.

The variation of global impedance became statistically significant after three months only in Mp1+2 (Fig.1a). We may speculate that extra-cochlear fibrosis around the case electrode is more pronounced and late than around the intra-cochlear one.

\section{Statistical pairing over time between global impedance} and $T / C$ values

In our data, there is an evident inverse correlation between impedances and T-level values: high impedance values correspond to lower electrical intensity (Fig. 2).
This behaviour is in strong agreement with the relationship of these variables stated by Ohm's law $(\mathrm{R}=\mathrm{V} / \mathrm{I})$ and other findings in the literature ${ }^{15}$. According to Kawano ${ }^{26}$, T-values correlate especially with the amount of fibrous tissue and also with new bone. Global T- and C-levels correlate with IV until t6 in M1+2 and in CG mode (Table II and Figs. 2a and 2b).We may speculate that intra-cochlear variables influenced global $\mathrm{T}$ and $\mathrm{C}$ values up to t6.

\section{Segregated statistical analysis for apical, middle and basal electrodes over time}

Our segregated data over time showed a slight increase, although not significant, in basal impedance over time (Table I and Fig. 1b) and a slight decrease for the apical segment at 12 (Fig. 1b), with no consistent pattern for the middle electrode segment.

The behaviour of the higher basal impedances compared to middle and apical ones (Fig. 3) agree with the data by Busby ${ }^{15}$ even if a different electrode array was used.

The higher basal impedance suggests the intervention of biological, intra-cochlear factors that may act in a different way depending on the cochlear regions. In the basal cochlear segment, a relative increase of impedance may be explained by a consistent production of scar tissue. Instead, in the apical region, the lower impedance may be due to a progressive adherence of conductive molecules that lead to an increase of a virtual electrical surface and thus to the decrease of impedance ${ }^{27}$. Probably both capacitive and resistive components of impedance change inside the cochlea, with prevalence of resistive in basal and conductive in apical.

Henkin ${ }^{13}$ found no differences between impedances among cochlear segments, but their data are not directly comparable to our study because the population and implants are different; they evaluated a paediatric population with lateral wall implant, while our study considered adults with a perimodiolar array.

Molisz ${ }^{28}$ found differences between the impedances among cochlear segments: the mid-portion and apical electrodes showed a decrease in impedance values in the first 6 postoperative months and stabilisation in the later course. The impedance of basal electrodes increased during the first 6 postoperative months and stabilised later on, but remained higher than the mid and the apical electrode impedance. In our study, we found similar results.

Kumar ${ }^{29}$ estimated that $75 \%$ of the electric current delivered by a cochlear implant is dispersed longitudinally in the scala tympani without stimulating the cells of the spiral ganglion. This large energy dispersion could be the basis for histological findings, while on the contrary, Fay$\mathrm{ad}^{8}$ hypothesised that this is due to surgical trauma alone. It is known that the cochleostomy procedure for insertion of the array causes immediate changes in the microstructure of the cochlea, such as trauma to the lateral wall, destruction of the spiral ligament and stria and damage in the lamina spiralis, basilar membrane, or modiolus ${ }^{30} 31$. 
Table III. (a) CG mean differences $(\Delta)$ and p-value for basal-middle-apical segregations at different time-points and (b) MP1+2 mean differences $(\Delta)$ and p-value for basal-middle-apical segregations at different time-points; ns=not significant values.

\begin{tabular}{|c|c|c|c|c|c|c|}
\hline$A$ & $\Delta$ Impedance & T-test & $\Delta$ Impedance & T-test & $\Delta$ Impedance & T-test \\
\hline CG mode & Basal-Apical: $\Delta$ & $\begin{array}{c}\text { Basal vs. Apical: } \\
\text { p }\end{array}$ & Basal-Middle: $\triangle$ & $\begin{array}{l}\text { Basal vs. } \\
\text { Middle: } p\end{array}$ & Apical-Middle: $\Delta$ & Apical vs. Middle: $p$ \\
\hline to & 0.4472 & 4.00E-09 & 0.1617 & $4.56 \mathrm{E}-04$ & -0.2855 & $1.98 \mathrm{E}-04$ \\
\hline $\mathrm{t} 1$ & 0.3647 & $1.68 \mathrm{E}-08$ & 0.2533 & $1.02 \mathrm{E}-10$ & -0.1114 & ns \\
\hline t3 & 0.4572 & $1.04 \mathrm{E}-12$ & 0.3148 & $2.06 \mathrm{E}-13$ & -0.1424 & $8.76 \mathrm{E}-03$ \\
\hline t6 & 0.4886 & $1.35 \mathrm{E}-12$ & 0.3571 & $1.05 \mathrm{E}-10$ & -0.1315 & ns \\
\hline $\mathrm{t} 12$ & 0.6568 & $4.20 \mathrm{E}-20$ & 0.4402 & 1.69E-17 & -0.2166 & 5.47E-05 \\
\hline
\end{tabular}

\begin{tabular}{lcccccc}
\hline B & $\begin{array}{c}\Delta \text { Impedance } \\
\text { Basal-Apical: } \Delta\end{array}$ & $\begin{array}{c}\text { T-test } \\
\text { Basal vs. Apical: } \\
\text { MP1+2 mode }\end{array}$ & $\begin{array}{c}\Delta \text { Impedance } \\
\text { Basal-Middle: } \Delta\end{array}$ & $\begin{array}{c}\text { T-test } \\
\text { Basal vs. } \\
\text { Middle: } \mathbf{P}\end{array}$ & $\begin{array}{c}\Delta \text { Impedance } \\
\text { Apical-Middle: } \Delta\end{array}$ & $\begin{array}{c}\text { T-test } \\
\text { Apical vs. Middle: } \mathbf{p}\end{array}$ \\
t0 & 0.3807 & 0.003 & 0.0929 & Ns & -0.2878 & 0.048 \\
t1 & 0.3124 & $<0.0001$ & 0.1863 & $<0.001$ & -0.1261 & $\mathrm{~ns}$ \\
t3 & 0.4010 & $<0.0001$ & 0.2413 & $<0.003$ & -0.1598 & $\mathrm{~ns}$ \\
t6 & 0.4504 & $<0.0001$ & 0.2776 & $<0.0018$ & -0.1728 & $\mathrm{~ns}$ \\
t12 & 0.6339 & $<0.0001$ & 0.3736 & $<0.0001$ & -0.2603 & 0.01 \\
\hline
\end{tabular}

Late changes may originate from host reactions to the presence of the array and involve inflammation, fibrosis and bony tissue growth. Trauma to the insertion site may also be introduced by bone dust coming into contact with the perilymph, which may contribute to fibrosis and osteoneogenesis ${ }^{9} 32$.

Our data indicating an higher basal segment impedances, where the highest electrical leakage is possible, are consistent with the findings of histological studies by Fayad $^{8}$ : in 11 patients who underwent cochlear implant surgery, they found that almost all of the fibrosis and osteoneogenesis occurred in the basal turn. The authors stated that the period between the surgeries until CI-user death (range 0.9 to 12.9 years) had a negative correlation with the amount of fibrosis in the basal cochlear segment, while the bone tissue growth tended to have a positive correlation in that segment. This reported trend and our data lead us to hypothesise that for our study subjects (i.e. with up to one year of follow-up), fibrosis (and not osseous growth) could be the main attribute responsible for the changes we observed in the impedances measured.

For our patient group, the same cochleostomy approach was applied; therefore, the resultant high impedances in basal electrodes could be due to such an insertion technique compared to the round window route. Against this hypothesis, however, are the histological findings of Fay$\mathrm{ad}^{8}$ which in 5 round window surgeries compared to 5 cochleostomy technique cases, no significant differences were detected in the amount of fibrosis, bone growth or other characteristics in general of the newly formed tissue or in residual sensorineural cells. Nadol ${ }^{33}$ report that in 12 of $21(57 \%)$ of temporal bones in implanted patients, there was a cellular response of inflammatory type with mononuclear leukocytes, histiocytes and foreign-body giant cells revealing that these reactions are much more intensive proximal to the cochleostomy site, which means that the inflammatory cells may persist in the long term even after implantation.

In our results, there is a clear correlation between T-level, C- level and impedances in M1+2 up to t6 for apical, middle and basal segments. In CG mode, $\mathrm{T}$ and $\mathrm{C}$ correlates up to $\mathrm{t} 3$ for apical and middle segments, and up to $\mathrm{t} 12$ for basal electrodes.

Thus, the disappearance of correlation at $\mathrm{t} 6$ and $\mathrm{t} 12$ for cochlear apical and middle segments (Table II, no global T-level differences after $\mathrm{t} 3$ ) seems to suggest stabilisation of intracochlear fibrosis after this period in these regions. Different timing results were obtained for basal electrodes that show significant correlation from t 0 up to 12 , suggesting a stronger and/or prolonged importance of intra-cochlear factors in determining fitting parameters at this cochlear segment.

In conclusion, our results indicate an increase in absolute basal electrode impedances compared to middle and apical ones at different observation times. The higher proportion of newly formed tissue in the basal region, as reported in other studies, may explain this overall picture. There is a good linear correlation of impedance values with parameters of fitting that agrees with Ohm's law: higher IVs correspond to both lower $\mathrm{T}$ and $\mathrm{C}$ levels.

\section{Conclusions}

In conclusion, our results indicate an increase in absolute basal electrode impedances compared to middle and apical ones. The higher proportion of newly formed tissue in the basal region, as reported in other studies, may explain 
this overall picture. The significant correlation between IVs and $\mathrm{T}$ and $\mathrm{C}$ values in the basal segment over time (up to t12) suggests to using more caution during fitting of basal electrodes.

\section{References}

1 House WF. Cochlear implant: My perspective. Newport Beach All Hear 1995.

2 Clark GM. The multiple-channel cochlear implant: the interface between sound and the central nervous system for hearing, speech, and language in deaf people-a personal perspective. Philos Trans R Soc Lond B Biol Sci 2006;361:791-810.

3 Blamey P. Are spiral ganglion cell numbers important for speech perception with a cochlear implant? Am J Otol 1997;18:S11-2.

4 Fayad JN, Linthicum FH Jr. Multichannel cochlear implants: relation of histopathology to performance. Laryngoscope 2006;116:1310-20.

5 Linthicum FH Jr, Fayad JN. Spiral ganglion cell loss is unrelated to segmental cochlear sensory system degeneration in humans. Otol Neurotol 2009;30:418-22.

6 Duan YY, Clark GM, Cowan RS. A study of intra-cochlear electrodes and tissue interface by electrochemical impedance methods in vivo. Biomaterials 2004;25:3813-28.

7 Nadol JB Jr. Patterns of neural degeneration in the human cochlea and auditory nerve: implications for cochlear implantation. Otolaryngol Head Neck Surg 1997;117:220-8.

8 Fayad JN, Makarem AO, Linthicum FH Jr. Histopathological assessment of fibrosis and new bone formation in implanted human temporal bones using 3D-reconsruction. Otolaryngol Head Neck Surg 2009;141:247-52.

9 Clark GM, Shute SA, Shepherd RK, et al. Cochlear implantation: osteoneogenesis, electrode-tissue impedance, and residual hearing. Ann Otol Rhinol Laryngol Suppl 1995;166:40-2.

10 Swanson B, Seligman P, Carter P. Impedance measurement of the nucleus 22-electrode array in patients. Ann Otol Rhinol Laryngolsuppl 1995;166:141-4.

11 Henkin Y, Kaplan-Neeman R, Muchnik C, et al. Changes over time in electrical stimulation levels and electrode impedance values in children using the Nucleus 24M cochlear implant. Int J Pediatr Otorhinolaryngol 2003;67:873-80.

12 Henkin Y, Kaplan-Neeman R, Muchnik C, et al. Changes over time in the psycho-electric parameters in children with cochlear implants. Int J Audiol 2003;42:274-8.

13 Henkin Y, Kaplan-Neeman R, Kronenberg J, et al. A longitudinal study of electrical stimulation levels and electrode impedance in children using the Clarion cochlear implant. Acta Otolaryngol 2006;126:581-6.

14 Henkin Y, Kaplan-Neeman R, Kronenberg J, et al. Electrical stimulation levels and electrode impedance values in children using the Med-El Combi 40+ cochlear implant: a one year follow-up. J Basic Clin Physiol Pharmacol 2005;16:127-37.

15 Busby PA, Plant KL, Whitford LA. Electrode impedance in adults and children using the Nucleus 24 cochlear implant system. Cochlear Implants Int 2002;3:87-103.

16 van Wermeskerken GK, van Olphen AF, Smoorenburg GF, et al. Intra- and postoperative electrode impedance of the straight and Contour arrays of the Nucleus 24 cochlear implant: relation to T and C levels. Int J Audiol 2006;45:537-44.

17 Lehnhardt E. Intracochlear placement of cochlear implant electrodes in soft surgery technique. HNO1993;41:356-9.

18 Cohen NL. Cochlear implant soft surgery: fact or fantasy? Otolaryngol Head Neck Surg 1997;117:214-6.

19 Laszig R. Cochlear implants in children (soft surgery). Adv Otorhinolaryngol 2000;57:87-9.

20 James C, Albegger K, Battmer R, et al. Preservation of residual hearing with cochlear implantation: how and why. Acta Otolaryngol 2005; 125:481-91.

21 Mosca F, Grassia R, Leone CA. Longitudinal variations in fitting parameters for adult cochlear recipients. Acta Otorhinolaryngol Ital 2014;34:111-6.

$22 \mathrm{Jia} \mathrm{H}$, Venail F, Piron JP, et al. Effect of surgical technique on electrode impedance after cochlear implantation. Ann Otol Rhinol Laryngol 2011;120:529-34.

23 Zadrozniak M1, Szymański M, Siwiec H, et al. [Impedance changes in cochlear implant users]. Otolaryngol Pol 2011;65:214-7.

24 Su GL, Colesa DJ, Pfingst BE. Effects of deafening and cochlear implantation procedures on postimplantation psychophysical electrical detection thresholds. Hear Res 2008;241:64-72.

25 Vargas JL, Sainz M, Roldan C, et al. Long-term evolution of the electrical stimulation levels for cochlear implant patients.Clin Exp Otorhinolaryngol 2012;5:194-200.

26 Kawano A, Seldon HL, Clark GM, et al. Intracochlear factors contributing to psychophysical percepts following cochlear implantation. Acta Otolaryngol 1998;118:313-26.

27 Brummer SB, Turner MJ. Electrical stimulation with Pt electrodes: I- A method for determination of 'real' electrode areas. IEEE Trans on Biomed Eng 1977;24:436-9.

28 Molisz A, Zarowski A, Vermeiren A, et al. Postimplantation changes of electrophysiological parameters in patients with cochlear implants. Audiol Neurootol 2015;9;20:222-8.

29 Kumar G, Chokshi M, Richter CP. Electrical impedance measurements of cochlear structures using the four-electrode reflection-coefficient technique. Hear Res 2010;259:86-94.

30 Cervera-Paz FJ, Linthicum FH Jr. Cochlear wall erosion after cochlear implantation. Ann Otol Rhinol Laryngol 2005;114:543-6.

31 Nadol JB Jr, Shiao JY, Burgess BJ, et al. Histopathology of cochlear implants in humans. Ann Otol Rhinol Laryngol 2001;110:883-91.

32 Roland PS, Wright CG. Surgical aspects of cochlear implantation: mechanisms of insertional trauma. Adv Otorhinolaryngol 2006;64:11-30.

33 Nadol JB Jr, Eddington DK. Histologic evaluation of the tissue seal and biologic response around cochlear implant electrodes in the human. Otol Neurotol 2004;252:57-62.

Received: October 20, 2016 - Accepted: January 15, 2017

Address for correspondence: Francesco Mosca, Department of Otorhinolaryngology, Monaldi Hospital, via L.Bianchi $80100 \mathrm{Na}-$ ples, Italy. Tel. +39 081 7065159. Fax +39 081 7064270. E-mail: francesco.mosca1@alice.it 